\title{
Development and performance of a motorized cowpea threshing machine for small scale farmers in Nigeria
}

\author{
Fawohunre Ademola Jerome * and Olajide Omotayo Gabriel \\ Department of Agricultural and Bio-Environmental Engineering Technology, Rufus Giwa Polytechnic, PMB 1029, Owo, \\ Ondo State.
}

Publication history: Received on 28 July 2020; revised on 27 September 2020; accepted on 29 September 2020

Article DOI: https://doi.org/10.30574/gjeta.2020.5.1.0047

\begin{abstract}
A motorized cowpea threshing machine was developed and evaluated to meet the need of small - scale farmers in the developing countries especially Nigeria. A power rating of $0.75 \mathrm{~kW}$, fan speed of $826 \mathrm{rpm}$, beater speed of $418 \mathrm{rpm}$ were used for the design. The driver and driven pulleys of $59 \mathrm{~mm}$ and $198 \mathrm{~mm}$ were used respectively. Two varieties of cowpea were used to evaluate the performance of the machine. The evaluation results showed that average threshing efficiency, cleaning efficiency, percentage of grain damage and throughput capacity were determined to be 83.6, 71.1, $4.4 \%$, and $74.5 \mathrm{~kg} / \mathrm{hr}$ respectively for Ife brown variety and $84.9,68.5,4.7 \%$, and $73.0 \mathrm{~kg} / \mathrm{hr}$ respectively for IAR 48 variety. The investigation was conducted at three levels of moisture content of 13.5, 14.5 and $15.5 \%$ wet basis. Based on the performance of the machine, effective threshing of different varieties of cowpea with minimum grain loss, improved threshing capacity cleaning and efficiency were achieved and yet good quality products was achieved.
\end{abstract}

Keywords: Development; Cowpea; Threshing; Cleaning; Capacity

\section{Introduction}

Cowpea (vigna unguiculata (L.) Walp) is one of the most popular grain legumes in Africa as well as in some regions of America and Asia. Cowpea is often called 'black - eyed pea' due to its black or brown - ringed hylum. Cowpea is called the 'hungry - season crop' because it is the first crop to be harvested before the cereal crops [1]. Its fresh or dried seeds, pods and leaves are commonly used as human food. Since they are highly valuable as food, cowpeas are only occasionally used to feed livestock but the hay and silage can be an important fodder. Cowpea has great flexibility in use: farmers can choose to harvest them for grains or to harvest forage for their livestock, depending on economical or climatological constraints. A large number of cowpea species are cultivated worldwide as ornamentals (in garden, as shade trees), used as living fences and firebreaks, as soil binders, green manure, forage for honey bees, in agroforestry and reforestation, as pulp for paper production and medicine [2]. Cowpea seed is a nutritious component in the human diet, as well as a nutritious livestock feed. The protein in cowpea seed is rich in the amino acids, lysine and tryptophan compared to cereal grains. Cowpea can also be used at all stages of growth as a vegetable crop. The tender green leaves are an important food source in Africa and are prepared as a pot herb like spinach, immature snapped pods are used in the same way as snap beans, often being mixed with other foods. Green cowpea seeds are boiled as a fresh vegetable, or may be canned or frozen, the dry mature seeds are also suitable for boiling and canning [3].

Cowpea is one of the staple crops in Nigeria that provide much needed protein requirement in the dietary table [4,5]. It could be prepared in several ways for consumption such as boiling, grinding and processing into 'Akara ball', 'moinmoin' and so on [6].

\footnotetext{
${ }^{*}$ Corresponding author: Fawohunre Ademola Jerome

Department of Agricultural and Bio-Environmental Engineering Technology Rufus Giwa Polytechnic, PMB 1029, Owo, Ondo State.. 
Traditional (manual) or mechanical method is used to thresh cowpea. Manual threshing is achieved using cocoa bags or spreading large clean cloth or tarpaulin on the floor, laying a bundle of cowpea on the cloth and beating with heavy sticks [7] or using pestle and mortar for the threshing operation [8,9]. Mechanical threshing involves high technology which is very expensive, and hence beyond the reach of Nigerian small - scale farmers though it helps to maintain the quality of the final products with minimum drudgery $[5,10]$. Some imported cowpea threshers have been found unsuitable for threshing the local varieties $[10,11,12]$.

The development of agriculture in developing countries of the world depend on the part played by modern agricultural machinery and equipment. Many local cowpea threshers have been developed but reliable information and performance data on them are limited. There is need therefore to design, fabricate and evaluate the performance of a local cowpea thresher that provide lower cost and yet achieving good quality products. The objectives of this study are to:

- $\quad$ study some properties that enhance machine design parameters of most popular cowpea

- varieties which are grown in Nigeria

- design and fabricate a cowpea threshing machine suitable for indigenous varieties in Nigeria

- $\quad$ carry out performance evaluation of the machine

\section{Material and methods}

\subsection{Description and operating principles of the machine}

Component parts and the fabricated cowpea threshing machine are shown in Figures 1 and 2 respectively. The major components of the cowpea threshing machine are: the feeding unit, threshing unit, cleaning unit and frame. The feeding unit consists of the hopper which provides an inlet through which the cowpea is introduced into the machine for threshing. The hopper is made up of a $2 \mathrm{~mm}$ stainless steel metal plate thickness and located above the threshing drum to facilitate easy feeding and has an opening into the threshing unit. The threshing unit consists of the threshing drum, shaft and star - shaped beater. The drum is made up of a $2 \mathrm{~mm}$ stainless steel metal plate thickness. The drum is 570 $\mathrm{mm}$ long and $300 \mathrm{~mm}$ diameter. The beater were spaced $40 \mathrm{~mm}$ apart. The cleaning unit consists of a chaff outlet, a screen and a fan. The chaff outlet is located at the side of the threshing unit, it is closed when threshing and opened when required to discharge the chaff from the machine. The fan is centrifugal type and has four straight blades, (200 $\mathrm{mm} \times 95 \mathrm{~mm}$ ) arranged at $90^{\circ}$ to each other around the shaft. The threshed grains fall through the screen and collected through the outlet that was inclined to facilitate effective sliding of the cowpea grains while the lighter particles were blown off from the fan assembly. The entire threshing components were mounted on a frame network made of angle iron $40 \times 40 \mathrm{~mm}$. The overall dimension of the machine was $1370 \mathrm{~mm}$ height and $(390 \times 501) \mathrm{mm}^{2} \mathrm{base}$ area. The frame network gives support to all the units of the machine.

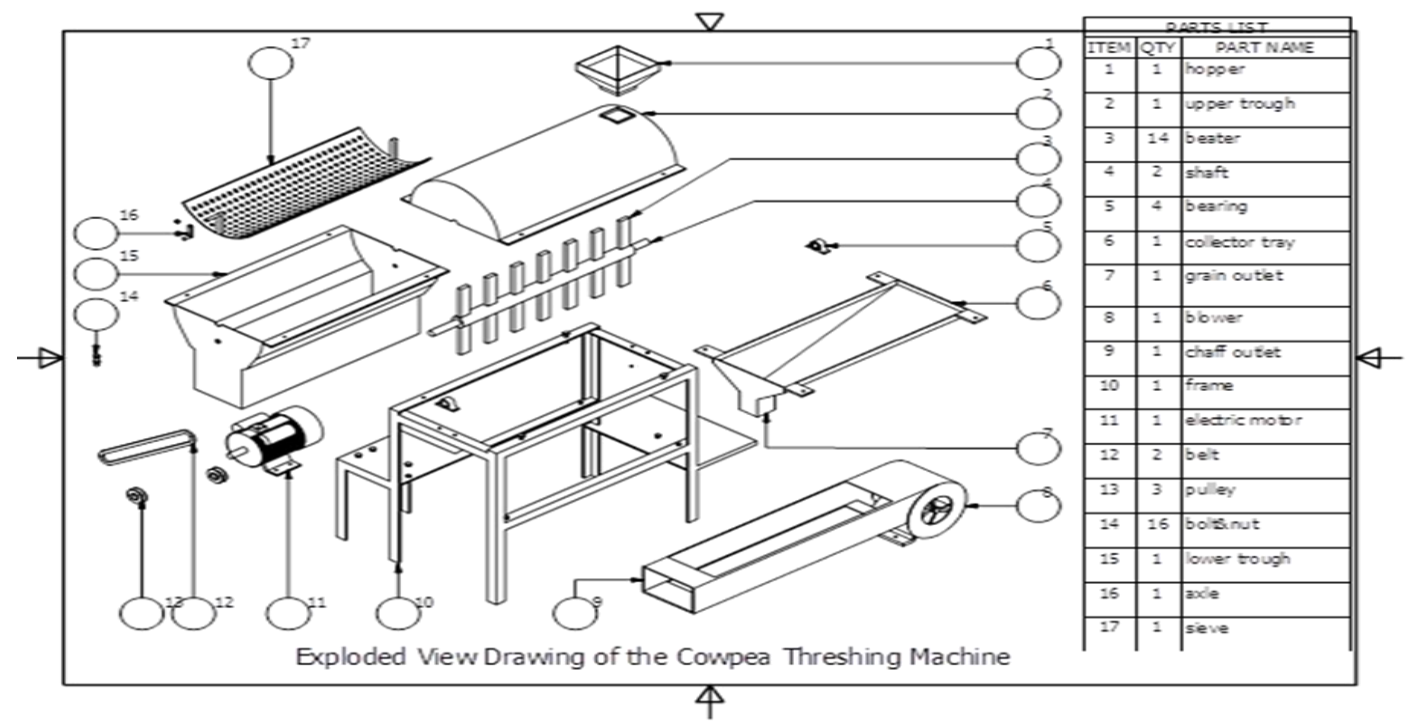

Figure 1 Component parts of the cowpea threshing machine 


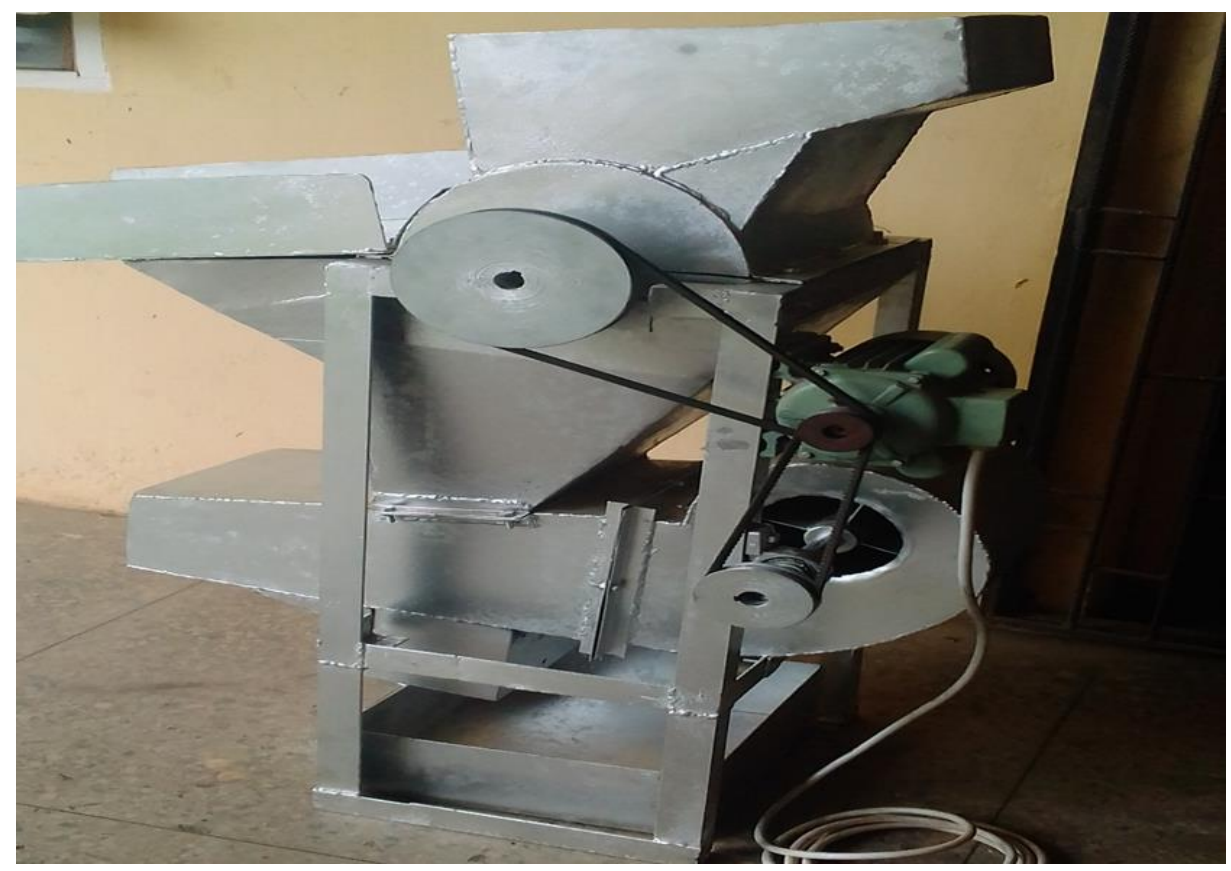

Figure 2 The fabricated cowpea threshing machine

\subsection{Design considerations}

The following factors were considered in designing the machine: power requirement, physical parameters of the materials to be threshed, simplicity, stability, feed rate, peripheral speed of the threshing drum, rigidity, number of beaters, durability and so on. The design focused on reduction of power and peripheral speed of the threshing. A beater - screen clearance suitable for threshing was considered. The beaters have provision for adjustments to suit variety of crops (grain sizes) to be threshed.

\subsection{Design analysis}

\subsubsection{Power requirement}

Determination of the power transmitted to drive the threshing drum is suggested by [7] as:

$$
P_{d}=F . v=\frac{M V^{3}}{R}
$$

Where $\mathrm{P}_{\mathrm{d}}=$ power required to drive the threshing drum $(\mathrm{kW}), \mathrm{F}=\mathrm{mv}^{2} / \mathrm{R}=$ centrifugal force, $\mathrm{m}=$ total mass of the threshing drum, $\mathrm{R}=$ radius of shaft, $\mathrm{V}=$ velocity and $\mathrm{g}=$ acceleration due to gravity. The power required to drive the threshing drum is $0.25 \mathrm{~kW}$. Thus, a motor of $0.75 \mathrm{~kW}$ was selected for the design.

\subsubsection{Belt design}

The determination of length of belt is given by [13]as:

$$
L=2 C+\frac{\pi}{2}\left(D_{2}+D_{1}\right)+\frac{\left(D_{2}-D_{1}\right)^{2}}{4 C}
$$

Where $\mathrm{L}=$ Pitch length of belt $(1104.5 \mathrm{~mm}), \mathrm{D}_{1}=$ Diameter of driver (motor pulley) (59 $\left.\mathrm{mm}\right), \mathrm{D}_{2}=$ Diameter of driven (threshing head pulley) (198 mm), C = Centre distance between drum and motor shaft $(325 \mathrm{~mm}), \pi=3.142$.

The determination of belt contact angle is given by [14] as:

$$
\theta=180^{\circ} \pm 2 \sin ^{-1} \frac{R_{2}-R_{1}}{C}
$$

Where $\theta=$ Contact angle for smaller and bigger pulleys. The contact angle $(\theta=3.1067 \mathrm{rad})$ of smaller pulley governs the design for accurate purpose, $\alpha=40^{\circ}$ (groove angle), $R_{1}=$ Radius of smaller pulley (29.5 mm), $R_{2}=$ Radius of larger pulley 
(99 mm), $C=$ center distance between $\mathrm{R}_{1}$ and $\mathrm{R}_{2}(325 \mathrm{~mm})$. The conventional negative and positive signs indicate the contact in the driver (smaller) and driven (bigger) pulleys respectively.

The determination of belt tension is given by [15] as:

$$
\frac{T_{1}-W}{T_{2}-W}=e^{\mu \theta /(\operatorname{Sin} \alpha / 2)}
$$

Where $\mathrm{T}_{1}=$ The Tension in the Tight Side of the Belt $(217.4 \mathrm{~N}), \mathrm{T}_{2}=$ The Tension in the Slack Side of the Belt, $(24.6 \mathrm{~N})$, $\mathrm{W}=\mathrm{MV}^{2},\left(\mathrm{M}=\right.$ Mass per unit Length of Belt, $0.157 \mathrm{Kg}, \mathrm{V}=$ Linear Velocity of Belt, $5.354 \mathrm{~ms}^{-1}, \mu=$ coefficient of friction (friction factor, 0.3) for rubber belt. Belt pull factor for $\mathrm{V}$ - belt is between 0.7 and 0.9 (above that, the belt will be unstable and wears at a faster rate. The belt pull factor calculated is 0.72 .

\subsubsection{Air discharge design}

The determination of air discharge through the blower was determined using the expression established by [16] as:

$$
Q=V \times D \times W
$$

Where $\mathrm{Q}=$ Air discharge $\left(1.648 \mathrm{~m}^{3} / \mathrm{s}\right), \mathrm{V}=$ Velocity of air required for cleaning $(v=2 \pi r n / 60=8.34 \mathrm{~m} / \mathrm{s}), \mathrm{D}=\mathrm{Depth}$ of air stream over the sieve $(0.075 \mathrm{~m}), \mathrm{W}=$ Width of fan blade $(0.095 \mathrm{~m})$

\subsubsection{Shaft design}

Shaft design consist primarily of the determination of the actual shaft diameter to ensure satisfactory strength and rigidity when the shaft is transmitting power through the various operation and loading conditions (vertical loading and horizontal loading).

Loads resulted due to weight of pulley acting downward, torque or radial force, weight of drum and reactions at the supports (bearing) is vertical loading while loads resulted due to tangential force, reactions at the support due to tangential force is horizontal loading.

The determination of drum shaft diameter and fan shaft diameter was determined using the expression given by [17] as:

$$
d^{3}=\frac{16}{\pi \sigma_{s}} \sqrt{\left(K_{b} M_{b}\right)^{2}+\left(K_{t} M_{t}\right)^{2}}
$$

where; $\mathrm{K}_{\mathrm{b}}=$ shock and fatigue factor applied to bending moment, $\mathrm{K}_{\mathrm{t}}=$ shock and fatigue factor to torsional moment, $\mathrm{M}_{\mathrm{t}}$ $=$ maximum torsional moment, $\mathrm{M}_{\mathrm{b}}=$ maximum bending moment, $\sigma_{\mathrm{s}}=$ Allowable design shear stress, $\mathrm{d}=\mathrm{shaft}$ diameter $(0.017 \mathrm{~m})$. If a safety factor of 1.4 is assumed for the design the shaft diameter is $23.8 \mathrm{~mm}$. Hence for reliability and safety a standard $25 \mathrm{~mm}$ diameter shaft was used for the drum.

Also, equation (6) was used to determine the fan shaft diameter: $\mathrm{d}=0.0165 \mathrm{~m}$. If a safety factor of 1.4 is assumed for the design the shaft diameter is $23.1 \mathrm{~mm}$. Hence for reliability and safety a standard $25 \mathrm{~mm}$ diameter shaft was used for the fan.

\subsubsection{Experimental design}

The developed machine was evaluated using the following parameters and indicators. Moisture content and feed rate are the crop parameters used for evaluation of the machine.

Moisture content - this was determined using oven dry method. The pods of the cowpea to be threshed were initially weighed and placed in the oven. The cowpea samples were removed from the oven and allowed to cool before reweighing and moisture content was determined according to procedure stated by [5].

$$
M c(100 \%)=\frac{W_{1}-W_{2}}{W_{1}} \times 100
$$

where $\mathrm{M}_{\mathrm{c}}=$ moisture content, $\mathrm{W}_{1}=$ initial weight, $\mathrm{W}_{2}=$ final weight . 
Feed rate - this is the ratio of the total mass of cowpea pod including grain, straw and chaff introduced into the threshing unit in batches to the time taken for the first and last grain crop to be discharged.

Threshing efficiency $\left(\mathrm{T}_{\mathrm{e}}\right)$, cleaning efficiency $\left(\mathrm{C}_{\mathrm{e}}\right)$, cleaning loss $\left(\mathrm{C}_{\mathrm{l}}\right)$, grain damage $\left(\mathrm{G}_{\mathrm{d}}\right)$, grain threshed and undamaged $\left(\mathrm{G}_{\mathrm{tu}}\right)$ and throughput capacity $\left(\mathrm{T}_{\mathrm{c}}\right)$ are the indicators used for evaluating the machine. These indicators were determined using the following equations as suggested by $[10,18]$.

$$
\begin{aligned}
& T_{e}(\%)=\frac{100 W_{A}}{W} \ldots \ldots \ldots \ldots \ldots \text { (8) } \\
& P_{d}(\%)=\frac{100 W_{B}}{W} \\
& P_{t u}(\%)=\frac{100 W_{C}}{W} \\
& C_{e}(\%)=\frac{100 W_{A}}{W_{A}+W_{D}} \\
& C_{l}(\%)=\frac{100 W_{E}}{W}
\end{aligned}
$$

Where $\mathrm{W}=$ total weight of the grain $(\mathrm{g}), \mathrm{W}_{\mathrm{A}}=$ threshed clean grains $(\mathrm{g}), \mathrm{W}_{\mathrm{B}}=$ threshed and damaged clean grains $(\mathrm{g})$, $\mathrm{W}_{\mathrm{C}}=$ threshed and undamaged clean grains $(\mathrm{g}), \mathrm{W}_{\mathrm{D}}=$ contaminants (chaff) in the grains $(\mathrm{g})$ and $\mathrm{W}_{\mathrm{E}}=$ grains in the chaff outlet (g).

\section{Results and discussion}

The picture of the fabricated cowpea threshing machine is shown in figure 2. The parameters of the machine is shown in Table 1 while the process and performance studies carried out on the machine using Ife brown and IAR 48 varieties at three different levels of moisture content $(13.5,14.5$ and $15.5 \%)$ is presented in Table 2.

Table 1 Parameters of the cowpea threshing machine

\begin{tabular}{|l|l|l|l|}
\hline S/N & Type & Symbols & Value \\
\hline 1 & Hopper volume & $\mathrm{V}$ & $0.0461 \mathrm{~m}^{3}$ \\
\hline 2 & Overall height & $\mathrm{H}$ & $1.370 \mathrm{~m}$ \\
\hline 3 & Threshing bar weight & $\mathrm{W}_{\mathrm{T}}$ & $2.84 \mathrm{Kg}$ \\
\hline 4 & Angular velocity & $\Omega$ & $88.7 \mathrm{rad} / \mathrm{s}$ \\
\hline 5 & Power calculated & $\mathrm{P}_{\mathrm{c}}$ & $0.25 \mathrm{~kW}$ \\
\hline 6 & Electric motor & $\mathrm{P}$ & $1 \mathrm{hp}$ \\
\hline 7 & Diameter of motor pulley & $\emptyset_{\mathrm{m}}$ & $0.059 \mathrm{~m}$ \\
\hline 8 & Diameter of beater pulley & $\emptyset_{\mathrm{b}}$ & $0.198 \mathrm{~m}$ \\
\hline 9 & Diameter of fan pulley & $\emptyset_{\mathrm{f}}$ & $0.1 \mathrm{~m}$ \\
\hline
\end{tabular}

Table 2 The process and performance studies on the cowpea threshing machine

\begin{tabular}{|l|l|l|l|l|l|l|}
\hline \multirow{2}{*}{ Performance indicators } & \multicolumn{3}{l|}{$\begin{array}{l}\text { Ife brown } \\
\text { moisture content } \\
\end{array}$} & \multicolumn{3}{l|}{$\begin{array}{l}\text { IAR 48 moisture } \\
\text { content (\%) }\end{array}$} \\
\cline { 2 - 7 } & $\mathbf{1 3 . 5}$ & $\mathbf{1 4 . 5}$ & $\mathbf{1 5 . 5}$ & $\mathbf{1 3 . 5}$ & $\mathbf{1 4 . 5}$ & $\mathbf{1 5 . 5}$ \\
\hline Threshing efficiency (\%) & 91.2 & 89.0 & 70.6 & 93.5 & 89.5 & 71.9 \\
\hline Cleaning efficiency (\%) & 79.1 & 70.4 & 63.7 & 75.4 & 68.8 & 61.4 \\
\hline Cleaning losses (\%) & 2.8 & 2.7 & 2.4 & 3.7 & 2.5 & 2.0 \\
\hline Grain damaged (\%) & 5.1 & 4.3 & 3.9 & 5.0 & 4.9 & 4.1 \\
\hline Grain threshed \& undamaged (\%) & 94.1 & 92.4 & 90.2 & 96.8 & 93.6 & 92.0 \\
\hline Throughput capacity (kg/hr) & 84.9 & 72.4 & 66.2 & 81.7 & 73.2 & 64.1 \\
\hline
\end{tabular}


The results obtained as contained in table 2 showed the performance indicators test carried on the fabricated machine. The threshing efficiency at three different moisture content levels of 13.5, 14.5 and 15.5\% at two different cowpea varieties (Ife brown and IAR 48) varies from 70.6 to $93.5 \%$. The threshing efficiency increased with decrease in moisture content and vice versa. It showed that moisture content had a significant effect on the threshing efficiency. Also, it was observed that IAR 48 cowpea variety is easier to thresh since the two varieties were at the same conditions. Cleaning efficiency was found in the range from 61.4 to $79.1 \%$. Optimum cleaning efficiency of $79.1 \%$ was achieved for Ife brown variety. Also, the results indicate that cleaning efficiency of the cowpea threshing machine increased as the moisture content decreases. It was observed that moisture content had significant effect on cleaning efficiency of the machine. The throughput capacity ranged from 64.1 to $84.9 \mathrm{~kg} / \mathrm{hr}$. The highest throughput capacity of $84.9 \mathrm{~kg} / \mathrm{hr}$ with Ife brown variety was recorded. Also, the throughput capacity of the cowpea threshing machine increased as the moisture content decreases. It showed that moisture content had significant effect on the throughput capacity of the machine. The results of the grains damage increased slightly with an increase in moisture content. The performance evaluation results of the machine were in agreement with findings of earlier researchers such as $[5,7,10,19]$.

\section{Conclusion}

Having carried out this research work, it can be concluded that; the cowpea threshing machine was designed and locally fabricated to meet the needs of Nigerian small - scale farmers. The machine is highly efficient, economical, dynamically stable and able to withstand vibration. The optimum threshing efficiency, cleaning efficiency and throughput capacity are $93.5 \%, 79.1 \%$ and $84.9 \mathrm{~kg} / \mathrm{hr}$ respectively. The performance indicators studied; increased with decrease in moisture content and vice - versa. The moisture content had significant effect on the performance indicators.

\section{Compliance with ethical standards}

\section{Acknowledgments}

The authors wish to acknowledge the Tertiary Education Trust Fund (TEFUND), Nigeria through Centre for Research and Development of Rufus Giwa Polytechnic, Owo for sponsoring this research.

\section{Disclosure of conflict of interest}

There are no conflicts of interest

\section{References}

[1] Gomez C. Cowpea: post - harvest operations in Mejia (ed), post - harvest compendium, AGST, FAO. 2004.

[2] Olajide OG, Fawounre AJ, Alagha SA. Development and performance evaluation of cowpea dehuller. International Journal of Advances in Scientific Research and Engineering. 2019; 5(8): 192 - 197.

[3] Davis DW, Oelke EA, Oplinger ES, Doll JD, Hanson CV and Putnam DH. Alternative field crops manual. University of Minnesota: center for alternative plant and animal products of the University of Minnesota. $1991 ; 72-80$.

[4] Olaoye JO. Development of a treadle operated abrasive-cylinder for threshing cowpea. International Journal of Engineering Science and Technology. 2011; 3(12): 8548 - 8557.

[5] Adekanye AT, Olaoye OJ. Performance evaluation of motorized and treadle Cowpea threshers, Agricultural Engineering International: the CIGR Journal. 2013; 15(4): 300 - 306.

[6] Lawrence K. Essentials of crop farming. Spectrum Books Limited. 2006; 101 - 120.

[7] Ogunlowo AS, Bello R. Design, construction and performance evaluation of a cowpea thresher. Journal of Agricultural Engineering and Technology. 2005; 13: 83 - 89.

[8] Phillips RD, McWatters KH, Beuchat LR, Chinnan MS, Hung YC, Eitenmiller RR, Sefa-Dedeh S, Sakya-Dawson E0, Stainer-Asiedu M and Lartey A. (2000). In: Processing and evaluation strategies to increase cowpea utilization. Bean/cowpea CRSP, Midcourse 2000. 
[9] Maunde FA. Performance evaluation of manual thresher. African Journal of Agricultural Research. 2011; 6(30): $6412-6415$.

[10] Irtwange SV. Design, fabrication and performance of a motorized cowpea thresher for Nigerian small - scale farmers, International Scholars Journals. 2020; 4(1): 001 - 009.

[11] Choudhury MS, Kaul RN. Alvan blanch threshers. Test report no. DAE/78-4. Department of Agricultural Engineering, Institute of Agricultural Research, Zaria, Nigeria. 1978.

[12] Adewumi BA, Ademosun OC, Ogunlowo AS. Design, fabrication and preliminary testing of a thresher-cleaner for grain legume. Journal of Food Science and Technology. 2007; 44(3): 276 - 280.

[13] Khurmi RS, Gupta JK. A textbook of machine design. Eurasia Publishing House (PVT) Limited Ram Nagar, New Delhi, India. 2006; $224-260$.

[14] Hannah J, Stephen R. 'Advanced Theory and Examples in Mechanics of Machines', Edward Arnold Ltd. New Delhi, India. 1st Edition. 2014; 677-819.

[15] Allen CA, Watts KC. Design of a belt thresher for cowpea beans. Agricultural Mechanization in Asia, Africa and Latin America. 1998; 29(3): 42 - 46.

[16] Joshi HC. Design and selection of thresher parameters and components. Agricultural Mechanization in Asia, Africa and Latin America. 1981; 11(2): 61 - 63.

[17] Ojomo A0, Fawohunre AJ. Development of a hammer mill with double sieving screens. European Journal of Engineering Research and Science. 2020; 5(5): 617 -621.

[18] Simonyan KJ, Yiljep YD. Investigating grain separation and clean efficiency distribution of a conventional stationary rasp-bar sorghum thresher. Agricultural Engineering International: the CIGR Ejournal Manuscript PM 07 028, X, August, 2008.

[19] Adetunji OR, Balogun BA, Fasasi AT. Development of a motorized maize shelling machine. Umudike Journal of Engineering and Technology. 2018; 4(2): $47-51$.

\section{Author's short biography}

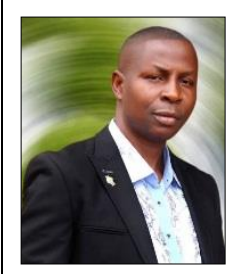

\section{Fawohunre Ademola Jerome}

Fawohunre A. Jerome is currently a lecturer in the department of Agricultural and Bio-Environmental Engineering Technology, Rufus Giwa Polytechnic, Owo with teaching and research experience of about fifteen years. He holds a Bachelor of Engineering from University of Agriculture, Makurdi, Benue State, Nigeria; Master of Engineering in Crop Processing and Storage Engineering from Federal University of Agriculture, Abeokuta, Ogun State, Nigeria. He has more than twenty publications in different reputable journal houses which cut across drying of agricultural products and design and fabrication of crop processing machines. He is a member of various professional bodies such as COREN, NSE, NIAE, IRDI and IAENG.

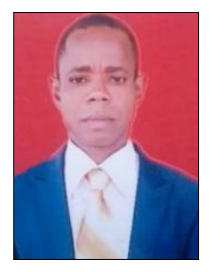

\section{Olajide Omotayo Gabriel}

Olajide 0. Gabriel is a lecturer in the department of Agricultural and Bio-Environmental Engineering Technology, Rufus Giwa Polytechnic, Owo with teaching and research experience of about 17 years. He holds Higher National Diploma in Farm Power and Machinery from Federal College of Agriculture, Ibadan, Oyo State, Nigeria; Master of Engineering from Federal University of Technology, Akure, Ondo State, Nigeria. He has over twenty - one publications which cut across farm power and machinery as well as crop processing engineering. He is a member of various professional bodies such as COREN, NSE, NIAE, IAENG and IRDI. 